cation until those members of the Royal Society who have studied the geology of Egypt can have opportunity to discuss it fully.

December 28 , I 885

\section{NOTES ON THE "MUIR GLACIER" OF} $A L A S K A$

I $\mathrm{N}$ a recent number of NATURE (vol. xxxii. p. I62) an abstract is made of a San Francisco newspaper account of the "Great Glacier" of Alaska. This account is not very accurate, and as I spent a few hours on this glacier during a flying visit to Alaska in the summer of I884, I think my observations may be worth recording. I have heard that some descriptions by American observers have already been published, but have not been able to procure them. However, as there are one or two features to which it may be useful to draw the attention of future explorers in this region, I will give my observations just as I made them, and apologise beforehand if they should be found to overlap those of others.

On August I, 1884 , I took passage from Victoria, Vancouver Island, on the steamer-on this occasion the Ancon-which carries the monthly mail from ports on Puget Sound to Sitka, Alaska, and eight days later we steamed up the long fiord known as "Glacier Bay," which opens into the Chilcoot Inlet, being then not far from latitude $59^{\circ} \mathrm{N}$. and longitude $136^{\circ} \mathrm{W}$. of Greenwich.

On either side of us high snow-capped mountains bordered the fiord, and in their recesses we could see glaciers of all sizes. One large mass filled a deep valley on our left, and reached nearly down to the sea, being apparently only separated from it by a ridge of moraine ; and everywhere little patches of blue rested in all the coulées near the mountain-tops, and showed by their trail of bare striated rocks and long strings of moraine how much further they must recently have extended.

Here and there a small island rose above the waters of the fiord, and, by its bare rounded outline and montonnéed surface, gave evidence that it, too, had once been overspread by the ice. The Indians say that one of these islands which is now above a mile distant from the Great Glacier, was embedded in the ice during their recollection, and I was told that early Russian charts of the coast do not show this fiord at all, but make note of a line of ice cliffs near its present entrance; but though the fiord has undoubtedly been at one time filled with ice, I cannot think that the period was so recent as this would indicate.

All round us the waters of the bay were strewn with masses of floating ice of beautiful colour and fantastic outline, but none were large. Right ahead, a gleaming wall of ice rose up out of the water and completely blocked the fiord, extending with a slight outward bulge from shore to shore. This was the "Great Glacier," or the "Muir Glacier" of Alaska.

In the account in NATURE it is stated that the height of the ice-wall is 500 feet, but I think this is an exaggeration. The master of our steamer thought its highest point might reach 450 feet; my own estimate would place it much lower even than this. Where I stood beneath it on the eastern shore I do not think it was more than 240 feet high, judging from the better-known height of an abutting cliff of sand and gravel presently to be described; but as the upper surface of the glacier appeared to be slightly domed, so as to be highest in the centre of the bay and lowest near the mountains, I should say that near the middle of the fiord the cliffs might be nearly roo feet higher than where I stood; but in my opinion they nowhere exceeded 350 feet.

The breadth of this ice-wall was about three miles. Huge masses were constantly splitting from it and sliding down into the sea with a loud dull roar. As they slid they raised a white dust-like cloud, and when they fell into the water great waves leaped in upon them and dashed high up the ice cliff, rebounding and causing every now and again a broad deep ground-swell which we could watch as it rapidly swept towards us.

The water through which we passed had changed when we first entered the fiord from the deep dark blue of the outer channel to a beautiful pale green, and now became quite clouded and of a milky greenish-white; and when we came nearer the glacier strong springs were observable, bursting up through the sea-water so as to rise slightly above its level. These were some little distance from the ice-cliff, which must have projected forward under water.

After having failed in an attempt to make fast to a grounded mass of ice-the largest near us - which rose up in pinnacles to the height of our somewhat stunted topmasts, we anchored near the right, or eastern, shore. Our party was then put ashore on a fine beach of washed sand and shingle, about half a mile from the foot of the glacier.

This beach is formed by the action of the waves on a mass of morainic material which is piled up irregularly between the shore and the bare mountain-side, and, where we landed, sloped back almost insensibly into the glacial gravels. But nearer the glacier the moraine had been cut back so as to form a low cliff, which in. creased in height as it approached the ice.

This cliff exhibited a clear and very interesting section, of which I made a sketch on the spot, shown in Fig. I.

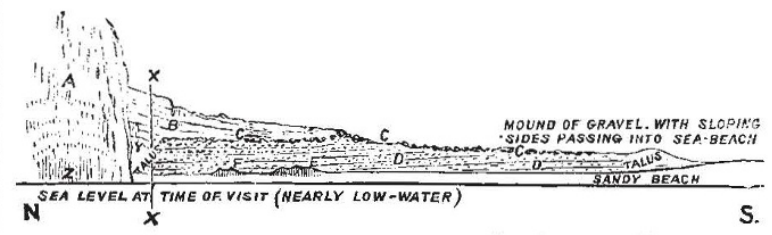

FIG. 1.-Sketch Section of Cliff at the head of Glacier Bay, Alaska, on the eastern shore, adjoining the glacier, Aug. 9, 1884. Leng th of section about 400 yards; height at $\mathrm{X}$ about ico feet.

A, Eastern end of terminal precipice of Muir Glacier, a nearly vertical wall of very clear blue ice, without stones: the ice shows lines of bedding towards the base, which are strongly curved over a dome. chaped cave $(z)$ from which issues a strong current of muddy water; this cave is filled by the sea at high tide; full height of ice wall, which is abont 240 feet here, is not shown.

$B$, Flange of very stony, dirty ice, apparently descending and flowing $\mathrm{B}$, Flange of very stony, dirty ice, apparent point some distance behind forward from the main mass of the glacier at $X$ : $X$ : this passes over the the line of section: about 60 feet thick at $X \ldots . X:$ this passes over the sands and gravels $\mathrm{D}$, and covers them for some distance, but rapidly bed $\mathrm{c}$.

c, Rubble of angular and water-worn boulders and febbles mixed with sand and clay; derived from the melting of the stony ice, $B$, whose lower layers are scarcely distinguishable from this bed.

$D$, Steep cliff of evenly-bedded sand and gravel; pebbles small and water-worn; shows signs of erosion at junction with c, but the bedding water-worn; shows signs of erosion at junct

E, A small boss of stony, bluish-gray clay resembling till, ontcropping E, A smail boss of stony, bluish-gray ciay resembling till, ont
below the sands and gravels : full of small water-worn pebbles.

below the sands and gravels: full of small water-worn pebbles.
F. Similar boss of fine gray clay without stones: no observab!e F, Sim

Notes.-In the above figure that part of the section marked $\mathrm{A}$ is not on the same plane as the rest, which recedes about 20 yards-the width of the seabeach.

A narrow gully $(y)$ had been excavated between A and D by water derived from the melting ice, and the lower part of the section was here obscured by talus: c crossed the head of this gully and joined the main mass of the glacier, but it was difficult to study this junction, as the ice of overhung the gully, and was constantly shedding masses into it.

The size of the patches of clay marked $\mathrm{E}$ and $\mathrm{F}$ is somewhat exaggerated in the section to make them apparent. I saw only a small surface of each rising above the beach in the cliff-foot; but from the manner of their outcrop I think they may form part of a clayey base on which the gravels rest.

I was not able to give much time to the study of this remarkable section, but was able to satisfy myself on the following points:--That a considerable thickness of evenly-bedded, water-worn gravel and sand was in close proximity to an almost vertical wall of ice, if not actually abutting on it. That this bedded gravel and sand was covered for some distance by a mass of dirty ice, full of stones, which was connected in some way with the main mass of the glacier. That the bedding of this deposit 
was in no way disturbed by either of these masses of ice. That a loose unstratified deposit containing both angular and water-worn pebbles and a little clay and sand, evidently the remainder-beds from the melting of the dirty and stony ice, overlay the bedded gravels. And that fine grey clay, in one place with stones, in another without, resembling glacial clays with which I am well acquainted, occurred below the bedded gravels.

A gentleman on board the steamer, Captain H. E. Morgan, of Port Townsend, W.T., with whom I had become acquainted during the voyage, had made several previous visits to the glacier; and we agreed to set out together for its upper surface as soon as we landed, and go as far along it as we could in the time allowed us.

We therefore struck out at once for the top, and, skirting the heaps of moraine which fill a large hollow space caused by the shrinking of the glacier from the mountainside, we soon commenced to ascend, passing diagonally along steep slopes of what looked like rough gravel, but was really stony ice covered with a thick crust of loose stones, as some dark water-pools and narrow crevasses soon showed.

Along these slopes we rose rapidly for some distance, the rubbly covering becoming thinner and thinner, till we emerged on a tolerably even plane of clear dark ice, with a rough and evidently rapidly-wasting surface which afforded excellent foothold.

I should think we were now at least half a mile from the mountain-side, and this space was altogether occupied by moraine or moraine-covered ice. Our elevation would be about that of the end of the glacier- 350 feet above sea-level. In front of us the surface rose rather steeply for another mile or so.

Up this slope we moved, following a course nearly parallel with the broad moraine on our right, which we had just crossed. On our left, at some distance from us, we could see another well-marked train of moraine, in which were many blocks of large size. The ice we were now passing over was very clear and unencumbered with debris, and of a magnificent pale blue tint. It was fissured transversely by deep crevasses, which, however, were not very wide, so that we could generally find a place to cross without diverging far from our course, though they seemed to widen as they left the margin of the glacier.

We went on in the same direction till we reached the crest of the slope. Up to this point I do not think the glacier anywhere exceeded a width of three miles, but now in front of us there lay a great expanse of ice which spread out like a lake, having a width which we estimated to be from six to eight miles. It seemed to me that from where we stood we looked slightly downward upon this basin. Numerous feeders poured into it on either side, one very large tributary coming in from a deep valley on our right about three miles distant, but its main gathering grounds were on some mountains at the head of the valley, which we estimated were about forty miles distant, our estimate being based on their appearance as compared with that of those off the mouth of the inlet, whose distance was known.

This basin discharged itself into the fiord by the steep slope we had just passed, which no doubt represented a similarly narrowed and increased slope in the buried valley beneath it. Our elevation here was probably not far short of 1000 feet. About three miles ahead of us an island of whitish rock cropped high up above the surface of the ice. This seemed to cause an eddy, as it were, in the current, there being a swerving of the ridges of ice on either side and a depression under its lee.

After passing the crest we found that the crevasses were no longer open, their sides coming together at a short distance below the surface, so as to form deep V-shaped troughs, or wells, which were filled with water of brilliant purity. The exquisite tints of blue deepening with the depth of the water exhibited by these ice pools made them a most beautiful spectacle. At the same time the surface of the glacier became very hummocky, so as to resemble a short cross-sea suddenly frozen, but as the decaying upper layer still afforded excellent foothold, and as there were now no black, open gulfs to startle one, travelling, though laborious, was quite practicable in any direction. We therefore changed our course and, striking out diagnnally, soon crossed the narrow moraine on our left. This, which would be about a mile from the edge of the ice, we found to consist chiefly of blocks of gray granite of all sizes, mixed with much sand formed by the decomposition of the small boulders which had often crumbled away into little heaps of grit. Beyond this there did not seem to be any rocky debris on the ice nearer than the moraines of the opposite shore, and the glacier consisted entirely of clear massive ice cut up into grooves and ridges. I noticed here and there amongst this clear ice, however, patches of small extent through which a muddy yellow stain was suffused. Seeking a cause for this, I found in the midst of one of these patches a pastylooking mass of gritty matter of the colour of rusted iron, forming a centre from which the stain had evidently diffused itself through the ice.

As this was not only far away from the moraine, but was also widely different from anything I had seen there, and as it did not in any way resemble an organic growth, I concluded that it might be of meteoric origin, and brought part of the mass away with me.

With the kind assistance of Mr. G. Carr-Robinson, F.R.S.E., F.C.S., I have lately been able to make a rough qualitative analysis of this substance, which has shown it to consist in great part of iron oxide, with a trace of nickel, and my suspicion that it may be a decomposed meteorite has thus been considerably strengthened. A more complete analysis will shortly be made. I hope that some future visitor to the locality will more thoroughly investigate this point, and carefully examine any stained ice which he may meet with in the body of the glacier. I took hasty notice of several instances, but only found this substance in the one case mentioned. A melting glacier of great age is certainly a likely place to reveal meteorites.

Capt. Morgan told me that once before when he was on the glacier he had come across the weathered bones of a bear protruding from the ice; he afterwards showed me one of the teeth which he had brought away with him.

After going a little further we found it was high time to return to the ship. There was now nearly two miles of ice and moraine between us and the mountain-side which bounded the glacier on our right, whilst on our left the ice still rose before us in broken hummocky ridges, with deep pools between. I pressed on alone to the crest of one of the ridges ahead of us, which promised a more extended view. Looking forward from this point, the surface seemed to become more and more broken, but I still could not see any open crevasses, and think it might have been possible to cross the glacier.

I then hurriedly retraced my steps, but instead of going directly back to the beach, swerved to the left, and passed down into the hollow between the glacier and the mountain-side to which I have already referred, wherein was heaped a great mass of moraine. This consisted chiefly of sand and gravel piled up in long ridges running roughly parallel with the flank of the glacier and with each other, with here and there a dangerous slough of soft tenacious mud between them, deposited by waters welling up from below. These ridges, of which there were three or four between the glacier and the mountain, were from 30 to 100 feet high, and were steeper on one side than the other; they seemed to contain both waterworn and angular pebbles, with a thin scattering of large blocks. I crossed two of them, but had not time to go 
further. To all appearance they were made up altogether of morainic matter, but in ascending the steep side of one of them I was surprised to find that my feet, after sinking through a few inches of loose stone, struck upon a hard surface of ice, and that the bulk of the ridge was made up of stony ice.

Seeing also that muddy water was welling out in the depression between this ridge and the next, I came to think that a buried portion of the glacier probably still underlay all this ground, perhaps even reaching down to the beach. Then, observing huge piles of similar material on the mountain-side, I concluded that a portion of the ice might remain hidden there also.

If this were so, then the downward pressure of this mass on the one hand against the sloping and partiallyburied flank of the glacier on the other would readily explain the presence of these ridges.

'This view of their origin is illustrated in the following diagram (Fig. 2), which I drew just after leaving the glacier; it would account for the mixture of water-worn and angular debris in the ridges, the former resulting from the watercourses between the glacier and the mountain, and the latter from the melting of stony ice.

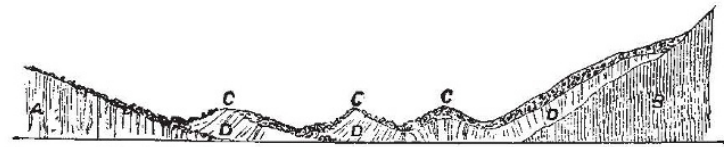

FIG. 2.--Ideal Section across the Moraine on the eastern flank of the Muir Glacier.

A, Eastern slope of the glacier: stony ice covered with a deep layer of loose stones.

B, Solid rock of the mountain-side.

c C C, Ridges apparently consisting of water-worn gravel and sand, with some angular debris, but probably hiding a core of stony ice, $D D$.

$\mathrm{D} D \mathrm{D}$, Buried portion of the glacier, supposed to exist below the moraine at C C C, and also on the mountain-side, which has been pressed up into ridges.

The ridges at the time of my visit were about half a mile in length, but may of course grow much longer as the glacier shrinks back. 'Though more or less regular, they were here and there interrupted and confused so as to form hollows surrounded by mounds, and in one case I noticed that the drainage of a gully had been dammed back so as to form a pond, in which the muddy water deposited much of its fine rock-flour, and issued out comparatively clear at the other side of the obstruction.

The boulders and pebbles of the moraine were chiefly of gray granite, but I noticed also quartzite, gneiss, a few fragments of slaty shale, and a mass of ancient-looking conglomerate- the last-named on the beach. During the day I saw only one scratched block; this was low down on the moraine near the beach.

We were now obliged to join the boat, which was waiting to take us back to the ship, and very much did I regret that circumstances would not permit me to stay longer.

Before leaving the ice-cliffs we fired a shot or two from our small signal cannon, to try to bring about an avalanche, but it had no perceptible effect, and the avalanches continued to choose their own time to fall.

This whole region forms a magnificent field for the study of glacial phenomena, and to any geologist who may follow I would especially say-examine the hollow between the ice and the mountains ; go to the foot of the ice-cliff at low water; and, wherever there is stained ice on the top of the glacier, trace out the source of the discolouration.

G. W. LAMPLUGH

\section{NOTES}

THE honour of knighthood was conferred upon Prof. Robert Stawell Ball, LL.D., Astronomer-Royal for Ireland, at the levée of the Lord-Lieutenant, on January 25.
LORD IDDESLEIGH has selected Mr. D. Morris, Director of the Public Gardens, Jamaica, for the appointment of Assistant Director of the Royal Botanic Gardens at Kew.

Dr. Riley, Entomologist to the United States Agricultural Department, has presented his collection of insects to the United States. It is said to contain II 5,000 specimens of 20,000 species or varieties of insects.

THE Committee of the François Arago centenary have appointed M. Mouchez, Director of the Observatory, President ; M. Floquet, President of the Chamber of Deputies, has been appointed Honorary President. The principal part of the celebration will take place at the Observatory.

M. PAUl Bert will not leave Paris so soon as was expected for Tonquin; the delay is occasioned by the organisation of the scientific part of his mission.

THE late M. Bertillon has bequeathed a sum of 4000 francs to the Paris Anthropological Society, to found a biennial prize to be awarded for the best work on some anthropological subject.

A sHock of earthquake was feit at about 7 o'clock on the morning of January 20 at St. Austell and in the neighbourhood. It appeared as if an explosion had taken place, so great was the noise, and the sound was immediately followed by the shaking of the ground. Persons felt their beds moving under them, and many others had an impression that a portion of their house was falling down. The shock was also felt at Mevagissey. Many people were shaken in their beds. In one instance a clock was stopped, and in many houses the doors and windows shook violently. The inhabitants of St. Blazey and neighbourhood were greatly startled, about a quarter past 7 , by hearing a loud rumbling noise and by houses being shaken from foundation to roof. It appeared to come from a northerly direction, and the vibration lasted about 4 or 5 seconds. Persons coming in from the outlying districts and giving an account of the shock being more or less severe all agree as to the time of its taking place.

A TELEGRAM from Mexico states that there was a renewed eruption on January 16 from the Colima volcano. Enormous stones were thrown out, and great streams of lava appeared. The eruption was accompanied by earthquakes.

Mr. J. Francis Cole, writing from Sutton, Surrey, informs us that he was a spectator of the remarkable meteor alluded to in our columns of the 2rst inst. (p. 278). As seen by him, the meteor appeared to explode or extinguish itself at a point about midway between the horizon and Capella, and was of a form like a well-shaped pear. It seemed so near that he felt he could have hit it with a stone. At the moment of exploding it opened in the centre of the lower part with a well-defined slit, and then widening, showed a light of the character of a hydrogen flame. The direction of the meteor was clearly from west to east, and at the same time the wind was blowing strongly from the west.

Amongst the objects of interest at the forthcoming Colonial and Indian Exhibition will be a rare collection of indigenous Australian grasses. The specimens are named to correspond with the nomenclature used in the "Flora Australiensis," and there is in addition much practical information about each, derived from general sources.

WE have received Prof. Baird's last Report on the work of the Smithsonian Institution, which deals only with the half year ending June 30 last, in consequence of a resolution of the Board of Regents directing that the fiscal year, instead of extending from January to December, shall, like the Government fiscal year, extend from July $I$ to June 30 in future. Amongst the publications promised by the Institution we notice the scientific 